\title{
Modeling wind-driven circulation during the March 1998 sediment resuspension event in Lake Michigan
}

\author{
Dmitry Beletsky, ${ }^{1}$ David J. Schwab, ${ }^{2}$ Paul J. Roebber, ${ }^{3}$ Michael J. McCormick, ${ }^{2}$ \\ Gerald S. Miller, ${ }^{2}$ and James H. Saylor ${ }^{2}$ \\ Received 1 October 2001; revised 26 June 2002; accepted 6 November 2002; published 19 February 2003.
}

[1] A three-dimensional primitive equation numerical ocean model was applied to Lake Michigan to simulate hydrodynamic conditions during the March 1998 sediment resuspension event in southern Lake Michigan caused by a storm with winds up to $20 \mathrm{~m} / \mathrm{s}$. The hydrodynamic model is driven with surface winds derived from observed meteorological conditions at 18 land stations and a meteorological buoy and also with surface winds calculated using a mesoscale meteorological model. Current observations from 11 subsurface moorings showed that the model driven with observed winds was able to qualitatively simulate wind-driven currents but underestimated current speeds during the most significant wind event. In addition, a pronounced offshore flow in the area of observations was also underestimated. Hydrodynamic model results using the meteorological model winds as the forcing function showed significant improvement over model results which were based on observed winds proving the importance of mesoscale winds for current modeling in large lakes. INDEX TERMS: 4255 Oceanography: General: Numerical modeling; 4546 Oceanography: Physical: Nearshore processes; 1845 Hydrology: Limnology; KEYWORDS: circulation modeling, Lake Michigan, sediment resuspension

Citation: Beletsky, D., D. J. Schwab, P. J. Roebber, M. J. McCormick, G. S. Miller, and J. H. Saylor, Modeling wind-driven circulation during the March 1998 sediment resuspension event in Lake Michigan, J. Geophys. Res., 108(C2), 3038, doi:10.1029/2001JC001159, 2003.

\section{Introduction}

[2] Satellite observations of surface reflectivity have revealed recurrent massive sediment resuspension events in Lake Michigan [Mortimer, 1988; Eadie et al., 1996]. The resuspension event of March 1998 was one of the largest events of record. Satellite observations (Figure 1) reveal a well-developed area of high turbidity extending along 300 $\mathrm{km}$ of coastline in southern Lake Michigan with several pronounced offshore features. The turbidity event began around 10 March following several days of intense storms that produced $20 \mathrm{~m} / \mathrm{s}$ northerly winds and generated waves in the basin over $6 \mathrm{~m}$ high. These observations are consistent with current understanding [Eadie et al., 1996] that the initiation of a turbidity event is caused by a major storm with strong northerly winds generating large waves in southern Lake Michigan. High turbidity appears along the entire southern coastline of the lake. Turbid water occasionally veers offshore along the eastern shore of the lake, coincidentally near the areas of highest measured long-term

\footnotetext{
${ }^{1}$ Department of Naval Architecture and Marine Engineering, University of Michigan, Ann Arbor, Michigan, USA.

${ }^{2}$ NOAA Great Lakes Environmental Research Laboratory, Ann Arbor, Michigan, USA.

${ }^{3}$ Department of Mathematical Sciences, University of WisconsinMilwaukee, Milwaukee, Wisconsin, USA.

Copyright 2003 by the American Geophysical Union. 0148-0227/03/2001JC001159
}

sediment accumulation in the lake [Foster and Colman, 1992].

[3] The recurrent turbidity event in southern Lake Michigan and associated nearshore-offshore water mass and material exchange is an object of intense study within a multidisciplinary research program called the Episodic Events- Great Lakes Experiment (EEGLE) (http://www. glerl.noaa.gov/eegle). The program is jointly sponsored by the National Oceanic and Atmospheric Administration (NOAA) and the National Science Foundation (NSF). In this paper we will investigate the dynamics of wind-induced circulation during a particular wind event in March 1998 because of the significant offshore transport associated with this event. To study the circulation pattern during this event, we use a three-dimensional hydrodynamic model driven by observed and modeled winds. This will allow us to test the sensitivity of the hydrodynamic model to mesoscale variability in the wind field. Current observations available at several moorings including Acoustic Doppler Current Profiler (ADCP) measurements are used to determine the accuracy of a hydrodynamic model driven by the two different types of meteorological data.

[4] The paper is organized as follows. The hydrodynamic model is described in section 2. Current observations and meteorological data are presented in sections 3 and 4 , respectively. Base model run results driven by objectively analyzed winds are analyzed and compared against observations in section 5 . In section 6 , base model run results are compared with the results driven by meteorological model 


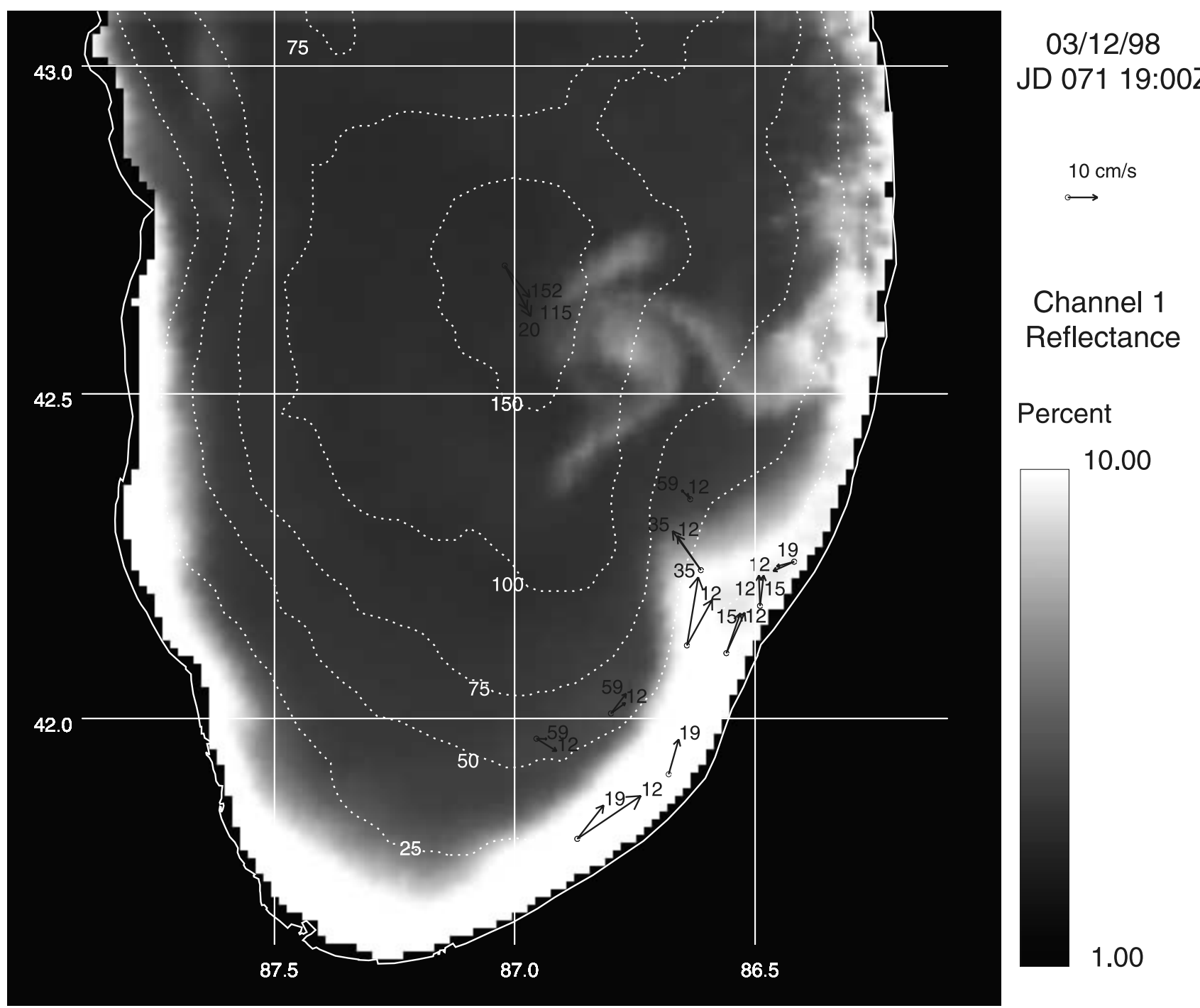

Figure 1. Satellite measurements of surface reflectance in southern Lake Michigan with currents at various depths observed at 1900 UTC, 12 March 1998.

winds. Discussion is presented in section 7. Summary and conclusions are given in section 8 .

\section{Hydrodynamic Model}

[5] A three-dimensional circulation model of Lake Michigan [Beletsky and Schwab, 2001] is used to calculate lake circulation. The model is based on the Princeton Ocean Model [Blumberg and Mellor, 1987] and is a nonlinear, hydrostatic, fully three-dimensional, primitive equation, finite difference model. The model uses time-dependent wind stress and heat flux forcing at the surface, free-slip lateral boundary conditions, and quadratic bottom friction. The drag coefficient in the bottom friction formulation is spatially variable. It is calculated on the basis of the assumption of a logarithmic bottom boundary layer using constant bottom roughness of $0.1 \mathrm{~cm}$. Horizontal diffusion is calculated with a Smagorinsky eddy parametrization (with a multiplier of 0.1) to give a greater mixing coefficient near strong horizontal gradients. The Princeton Ocean
Model employs a terrain following vertical coordinate system ( $\sigma$-coordinate). The equations are written in flux form, and the finite differencing is done on an Arakawa-C grid using a control volume formalism. The finite differencing scheme is second order and centered in space and time (leapfrog). The model includes the Mellor and Yamada [1982] level 2.5 turbulence closure parameterization.

[6] The hydrodynamic model of Lake Michigan has 20 vertical levels with finer spacing near the surface and the bottom and a uniform horizontal grid size of $2 \mathrm{~km}$ (Figure 2). Model bathymetry is based on the new, high-resolution bathymetric data for Lake Michigan [National Geophysical Data Center, 1996].

\section{Current Meter Data}

[7] A relatively high-density array of current meters moorings was deployed along the southeastern coast of southern Lake Michigan in order to measure storm induced coastal flow. Both Vector Averaging Current Meters (VACM) and 


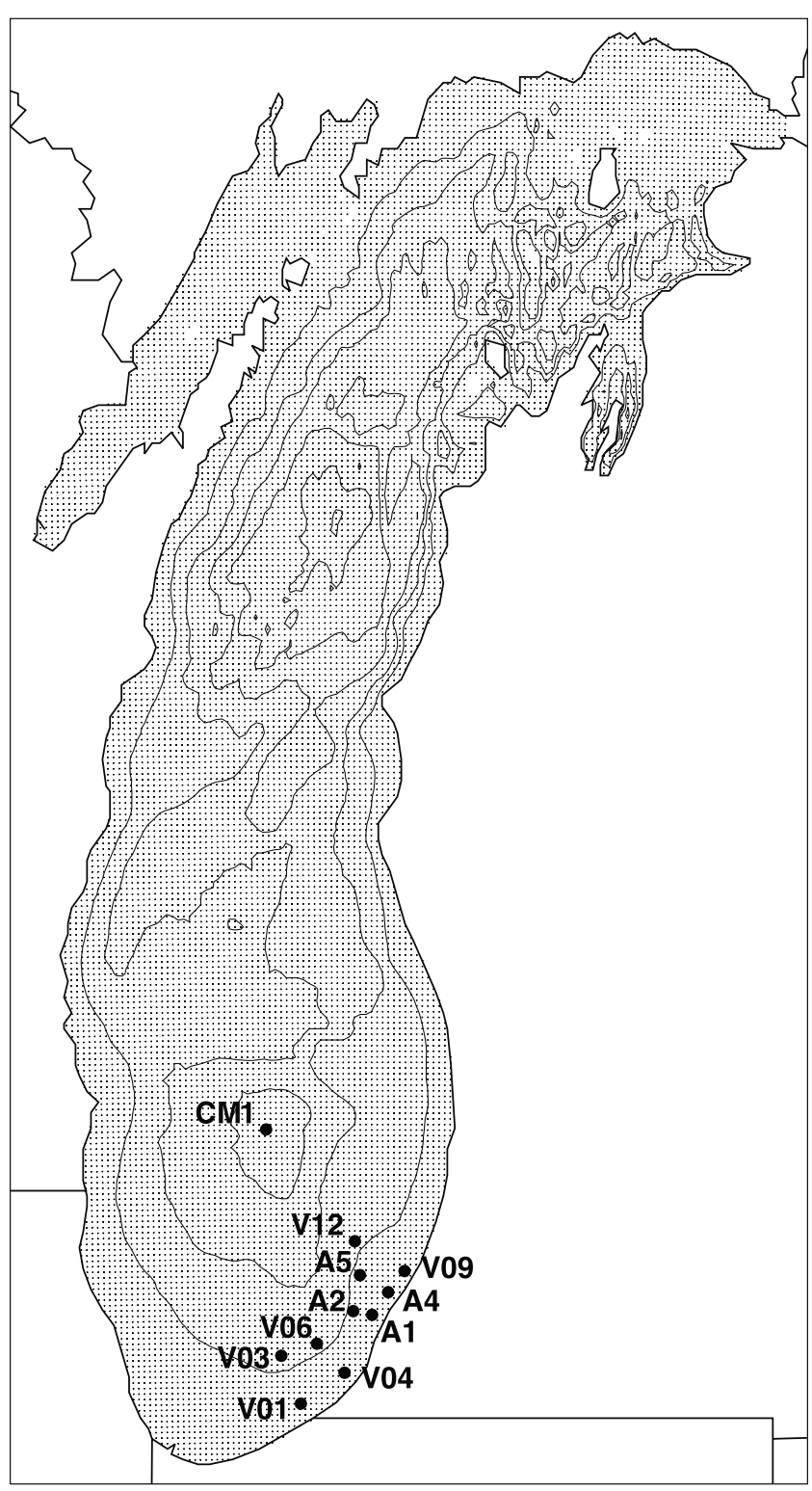

Figure 2. Current observation network and $2 \mathrm{~km}$ computational grid. Isobaths are every $50 \mathrm{~m}$.

ADCP instruments were used. The higher resolution ADCPs were deployed in a cluster near a well defined bathymetric feature where topographic steering of coastal flow can be a prominent source of offshore transport (Figure 2).

[8] The 1997-1998 measurements were carried out during the pilot year of the EEGLE program when 11 moorings were deployed at approximately 20, 40, and $60 \mathrm{~m}$ depths. The 4 central moorings (A1, A2, A4, and A5) were equipped with ADCPs deployed at 18 (A1 and A4) and $38 \mathrm{~m}$ (A2 and A5) depths while the remaining moorings (V01, V03, V04, V06, V09, and V12) deployed at 20 and $60 \mathrm{~m}$ depths had 2 VACMs each at $12 \mathrm{~m}$ and at $1 \mathrm{~m}$ above the bottom. Observations were made from October 1997 to June 1998. The midlake station (CM1) is a part of an ongoing monitoring program at NOAA Great Lakes Environmental Research Laboratory (GLERL) and had 3 VACMs at 20, 115, and $152 \mathrm{~m}$.

\section{Meteorological Data}

\subsection{Natural Neighbor Analyzed Data}

[9] We use a bulk aerodynamic formulation to calculate heat and momentum fluxes over the water surface at each grid point for the lake circulation model. Hourly meteorological data (wind speed and direction, air temperature, dew point and cloud cover) for March 1998 were obtained from 18 National Weather Service stations around Lake Michigan and National Data Buoy Center (NDBC) buoy 45002 (Figure 3). These observations form the basis for generating gridded meteorological fields. Details of heat and momentum flux calculations are presented by Beletsky and Schwab [2001]. Because overland wind speeds generally underestimate overwater values we apply the empirical over-

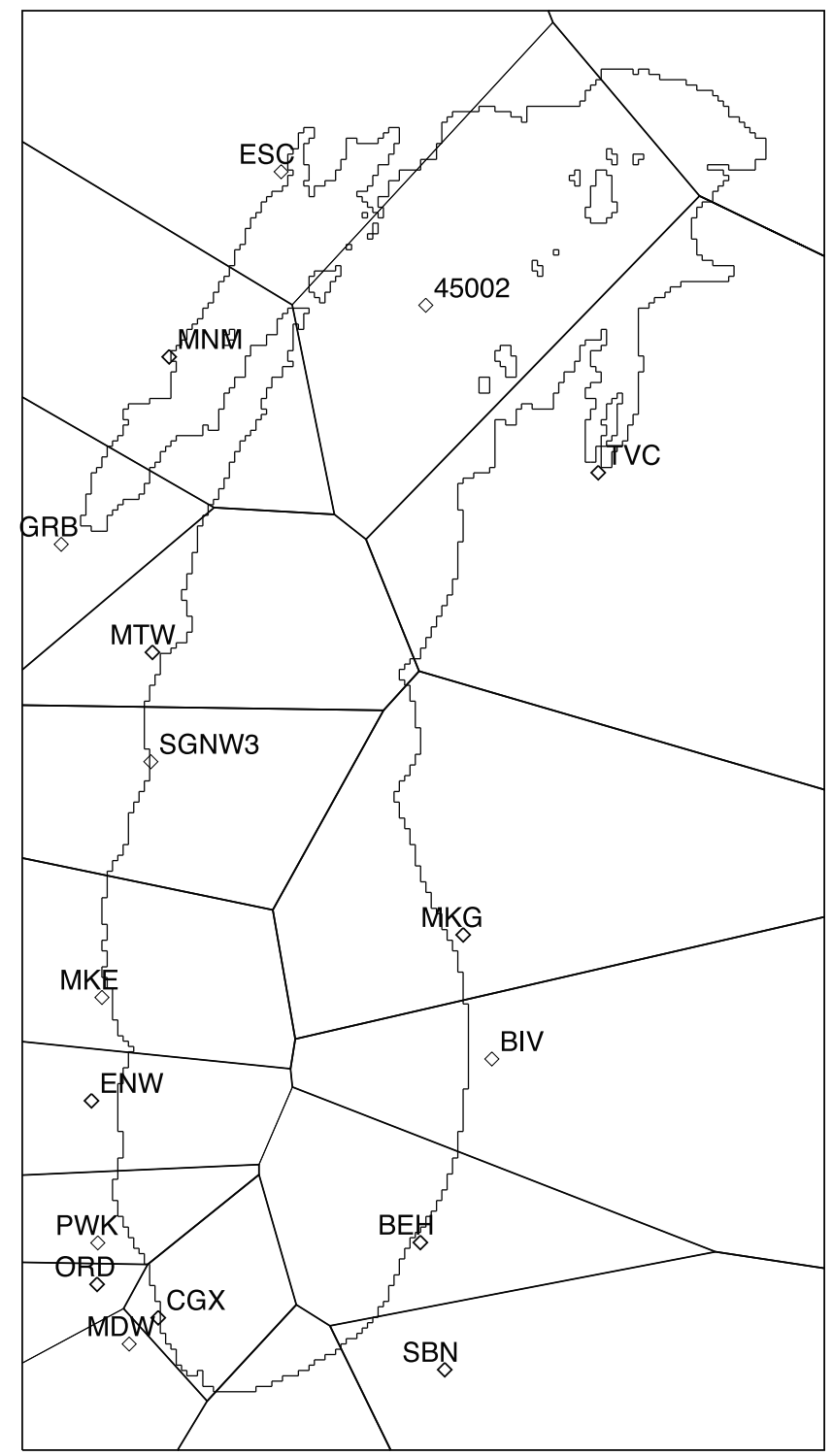

Figure 3. Meteorological observation network and corresponding Voronoi cells from Delaunay tessellation. Four distant "pseudo-stations" have been added at the corners of large rectangle bonding the region in order to insure complete coverage. 
land-overlake wind speed adjustment from Resio and Vincent [1977] to data from the 18 land stations.

[10] In order to interpolate meteorological data observed at irregular points in time and space to a regular grid so that it can be used for input into a numerical circulation model, some type of objective analysis technique must be used. In the past 10-20 years the so-called nearest-neighbor technique has routinely been used for this purpose. The nearest neighbor technique was used in the Lake Michigan Mass Balance Study models [Beletsky and Schwab, 2001] and in the Great Lakes Forecasting System (GLFS) models (http:// superior.eng.ohio-state.edu), but the GLFS models have subsequently adopted a new, geometrically based technique that appears to provide a more realistic representation of the two-dimensional wind field than nearest neighbor techniques. The approach is called "Natural Neighbor" interpolation and is based on the Delaunay triangulation of the station observation network (Figure 3). The "natural neighbors" of a particular point on the regular grid are determined by performing a Delaunay triangulation on a new set of points which includes the grid point as well as the observation points. The "natural neighbors" of the grid point are then the observation points which lie in the Voronoi cells surrounding the cell which contains the grid point. Observed meteorological variables from the observation points are weighted by the area of overlap between the new Voronoi cell corresponding to the grid point and the original Voronoi cell corresponding to the observation point. The weighted values are summed and divided by the sum of the weights to determine the value at the grid point. Details of the procedure are given by Sibson [1981] and Watson [1994].

[11] According to Sambridge et al. [1995], the method has the following useful properties: (1) the original function values are recovered exactly at the reference points; (2) the interpolation is entirely local (every point is only influenced by its natural neighbor nodes); (3) the derivatives of the interpolated function are continuous everywhere except at the reference points. Points 1 and 2 are especially important for the type of network we deal with in the Great Lakes; i.e., not every station is available at every hour and some stations appear only intermittently. This technique is also advantageous for interpolating data fields for which the spatial autocorrelation function is not well known, such as hourly wind fields.

\subsection{MM5 Model Based Winds}

[12] In addition to objectively analyzed winds we also used winds from a numerical meteorological model during the strongest northerly wind episode as the forcing function in order to compare results obtained by various methods. For that purpose, the Penn State/NCAR 5th generation mesoscale model (MM5) [Dudhia, 1993] was run for the period 7-12 March 1998. A triply nested domain configuration $(54 / 18 / 6 \mathrm{~km})$ with two-way interactions (such that exterior domains feel the influence of interior domains and vice versa) was employed, with the innermost nest providing $6 \mathrm{~km}$ grid point resolution in an area centered on Lake Michigan.

[13] Model initialization and lateral boundary conditions were determined as follows. First guess fields of atmospheric variables (wind, temperature, moisture) were obtained from the National Centers for Environmental Prediction historical archives of global $\left(2.5^{\circ}\right.$ latitude by $2.5^{\circ}$ longitude) mandatory-level analyses and were then adjusted using a Cressman-type objective analysis [Cressman, 1959] of surface and rawinsonde data for all stations within or near the grid domain. These analyses provided boundary conditions on the outermost grid domain throughout the course of the integrations and were used in the four dimensional data assimilation procedure described below.

[14] Vertical sigma levels were arranged such that the model output was available on a total of 23 levels, with a higher grid concentration at the lowest levels in order to resolve planetary boundary layer structure. The planetary boundary layer was modeled using a high-resolution Blackadar scheme [Blackadar, 1979] coupled with a five-layer soil model. Physiographic and land use patterns were backinterpolated from a high-resolution data set to the model grids.

[15] The surface and upper-air meteorological analyses described above were incorporated into the simulation using the four-dimensional data assimilation technique known as Newtonian Relaxation or nudging [Stauffer and Seaman, 1990]. In this technique an analysis dataset that provides time continuity and dynamic coupling among the various model fields is generated by weakly forcing the model solutions toward three-dimensional gridded analyses of wind, temperature and mixing ratio. In this way the model solution remains "bounded" by the observations, and the horizontal resolution of the observations is effectively enhanced by the added time dimension. The four dimensional data assimilation was used on the outermost $(54 \mathrm{~km})$ model domain only, to ensure that the synoptic-scale meteorological conditions remained consistent with the analysis over the 1 week period of the MM5 integration (7-13 March 1998).

\subsection{9-10 March 1998 Storm: Synoptic Analysis}

[16] In view of the particular significance of 9-10 March 1998 storm, we give a brief summary of synoptic conditions during this period. On 7 March 1998 a strong short-wave trough passed from the Pacific coast to the intermountain region of the United States. In response in part to the strong differential cyclonic vorticity advection in advance of this trough, a substantial surface circulation developed by 1200 UTC, with 7-10 $\mathrm{m} \mathrm{s}^{-1}$ east-northeast winds in Kansas and Colorado. In the Lake Michigan basin, winds were light and temperatures were near freezing during this time.

[17] The system intensified as it propagated eastward. By 1200 UTC 8 March 1998, the surface cyclone (with central pressure of $993 \mathrm{hPa}$ ) was positioned in southeastern Missouri, with a broad region of $10-20 \mathrm{~m} \mathrm{~s}^{-1}$ winds from the Great Lakes to central Texas (Figure 4). Over the following 24 hours the surface cyclone continued intensifying and propagated northeastward, reaching southwestern Lake Erie by 1200 UTC 9 March 1998, with a central pressure of 988 $\mathrm{hPa}$. The strongest winds were being reported in the northerly flow on the backside of the system, including winds up to $20 \mathrm{~m} / \mathrm{s}$ over Lake Michigan (Figure 5). By 1200 UTC 10 March 1998, the cyclone center was positioned in southern Quebec and the northerly flow across Lake Michigan had weakened to $5-7 \mathrm{~m} \mathrm{~s}^{-1}$. Cooler air was also in place across the Lake Michigan basin, with temperatures $5-10^{\circ} \mathrm{C}$ lower 

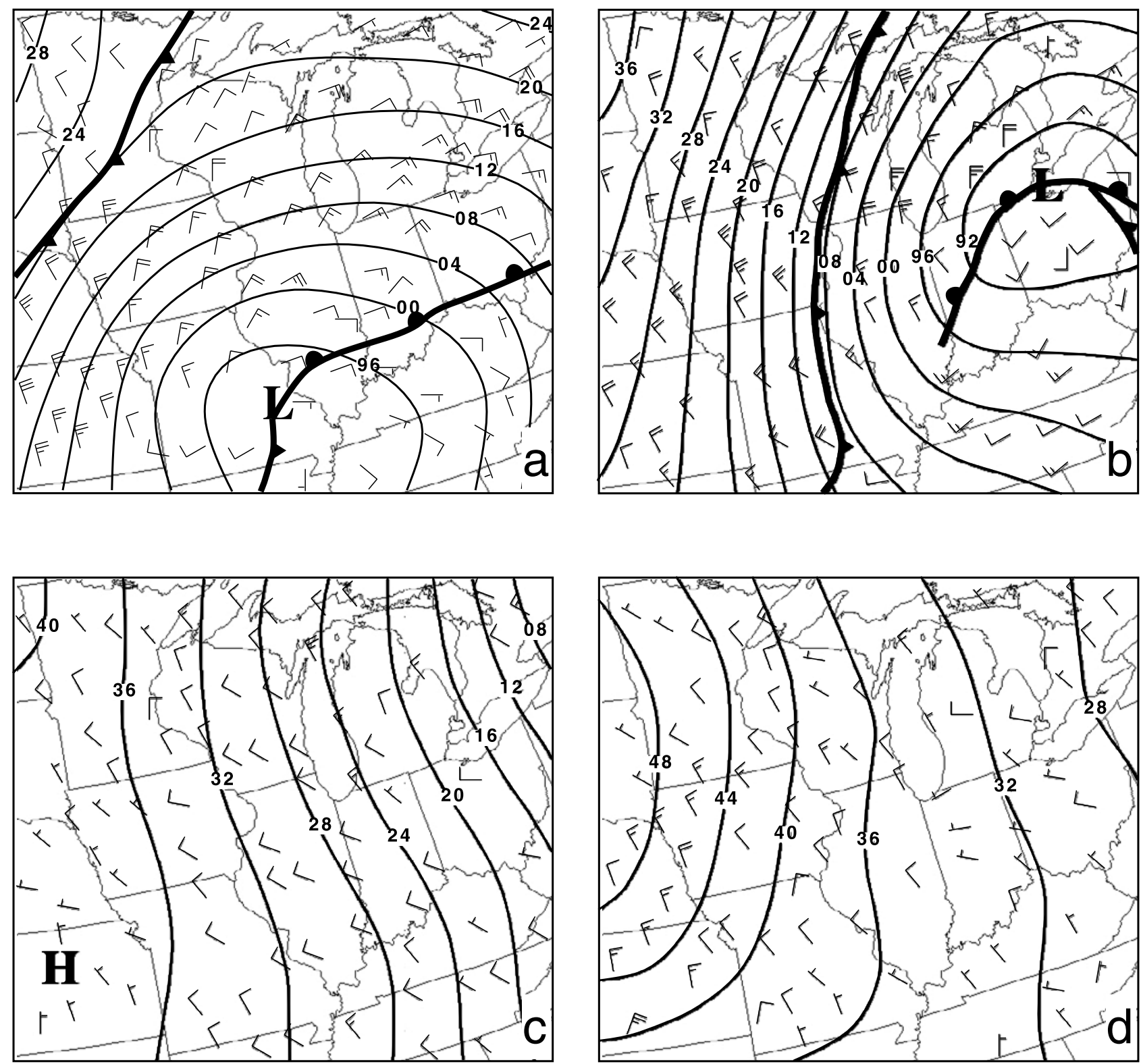

Figure 4. Synoptic analysis for (a) 8, (b) 9, (c)10, and (d) 11 March 1998 at 1200 UTC. Isobars: every 4 $\mathrm{hPa}$. Wind: full barb $-5 \mathrm{~m} / \mathrm{s}$, half barb $-2.5 \mathrm{~m} / \mathrm{s}$.

than the day before. On 11 March the cold temperatures and weak northerly flow persisted at the synoptic scale.

\section{Natural Neighbor Based Model Run and Comparison With Observations}

[18] All model runs begin on 1 March and end on 30 March. Initial currents are set to zero. In early spring the lake is thermally homogeneous and density gradients are negligible. Therefore the circulation model was initialized with uniform $\left(2^{\circ} \mathrm{C}\right)$ water temperature. Because water temperature did not change significantly during the model run, we restrict all future discussions to the momentum rather than heat flux effects. The base model run uses the meteorological fields generated with Natural Neighbor interpolation, and the MM5-based run results will be compared against it. The NDBC buoy 45002 located in

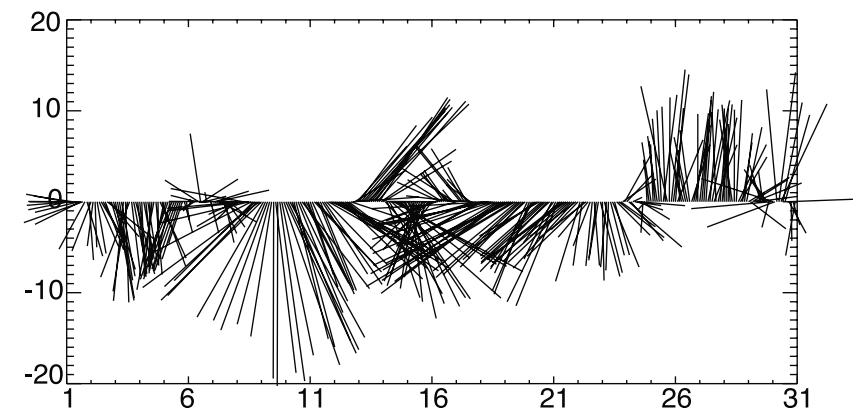

Figure 5. Time series of observed wind (adjusted to $10 \mathrm{~m}$ height, every other hour is shown) at NDBC buoy 45002 in March 1998. 

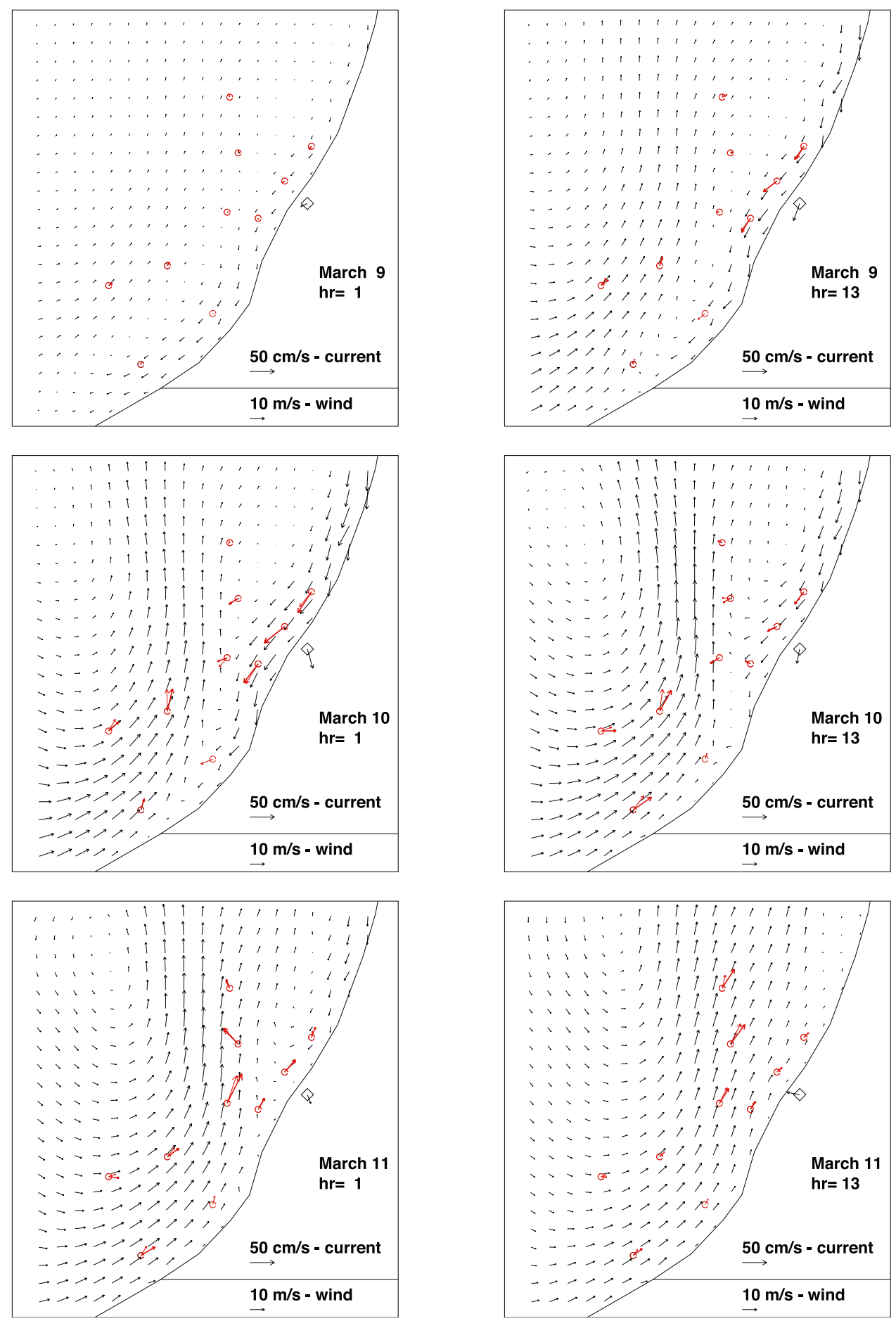

Figure 6. Modeled depth-averaged currents versus observed currents (12 $\mathrm{m}$ currents are shown in bold) in southern Lake Michigan on 9-11 March. Model is driven with observed wind. Hourly wind observations at Benton Harbor meteorological station (BEH in Figure 3) are also shown.

northern Lake Michigan provided valuable information on overwater winds in the Natural Neighbor analysis. As time series of wind from this buoy show, the storm on 9 March was the strongest during this month (Figure 5).

[19] The characteristic circulation pattern in a lake driven by a spatially uniform wind consists of two counter-rotating gyres, a counterclockwise-rotating (cyclonic) gyre to the right of the wind and a clockwise-rotating (anticyclonic) gyre to the left [Bennett, 1974]. The strongest currents are downwind in the coastal regions while weaker upwind return currents develop in the deeper waters. This two-gyre circulation pattern was clearly seen during the major northerly wind event in southern Lake Michigan. The wind caused strong longshore southerly currents on 9 March that converged initially south of station V01 and caused massive offshore flow (Figure 6). 
40 and 60 meter stations
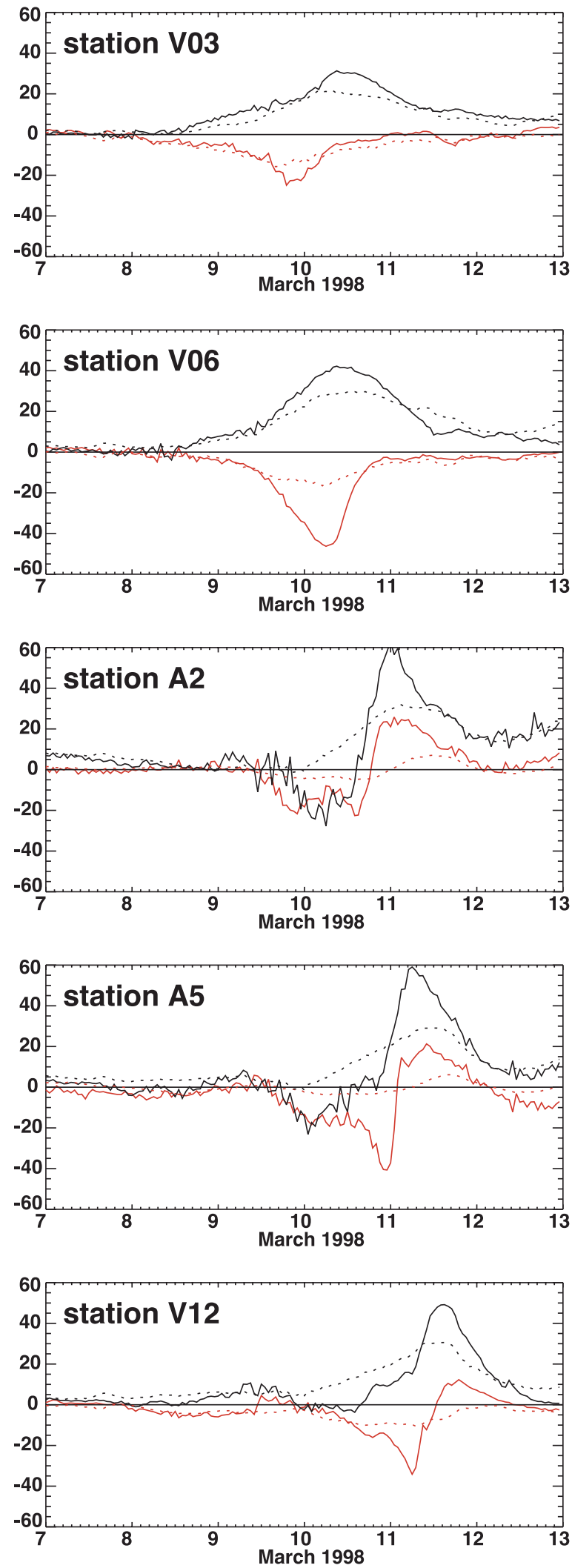

20 meter stations
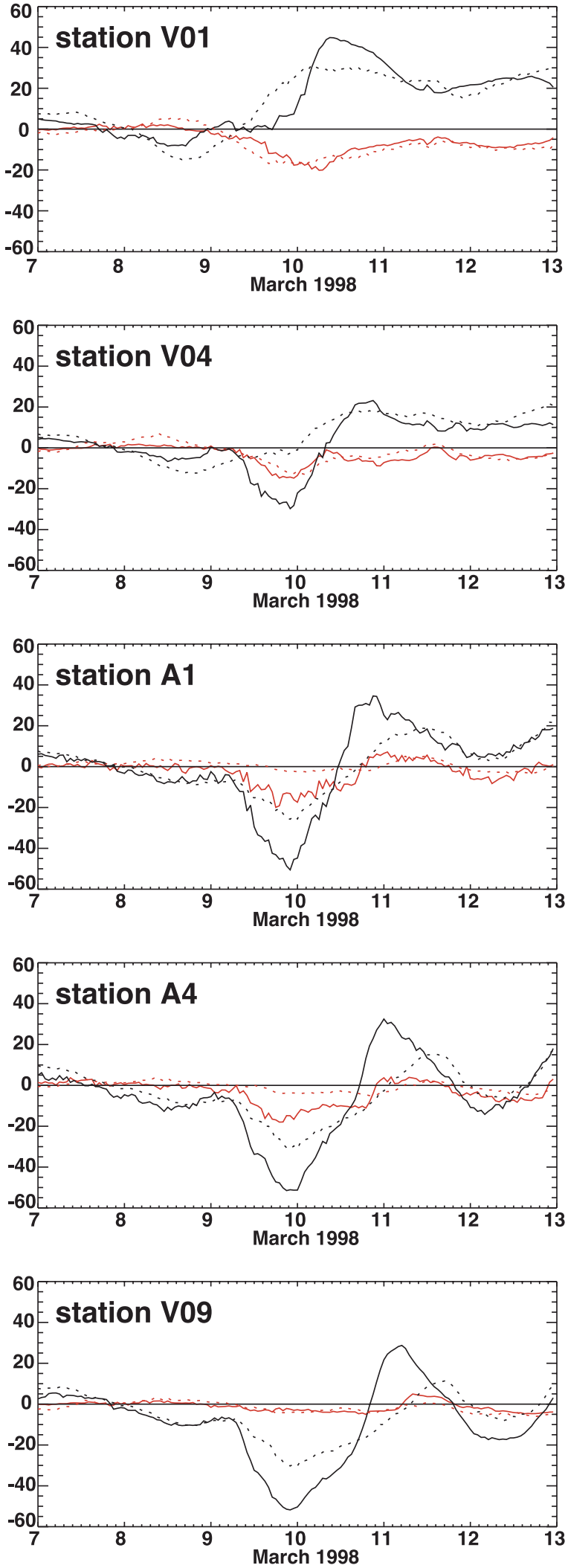

Figure 7. Longshore and offshore currents at $12 \mathrm{~m}$. Solid line is observations; dotted line is Natural Neighbor model results. Black represents longshore currents, and red represents onshore (positive) currents. 

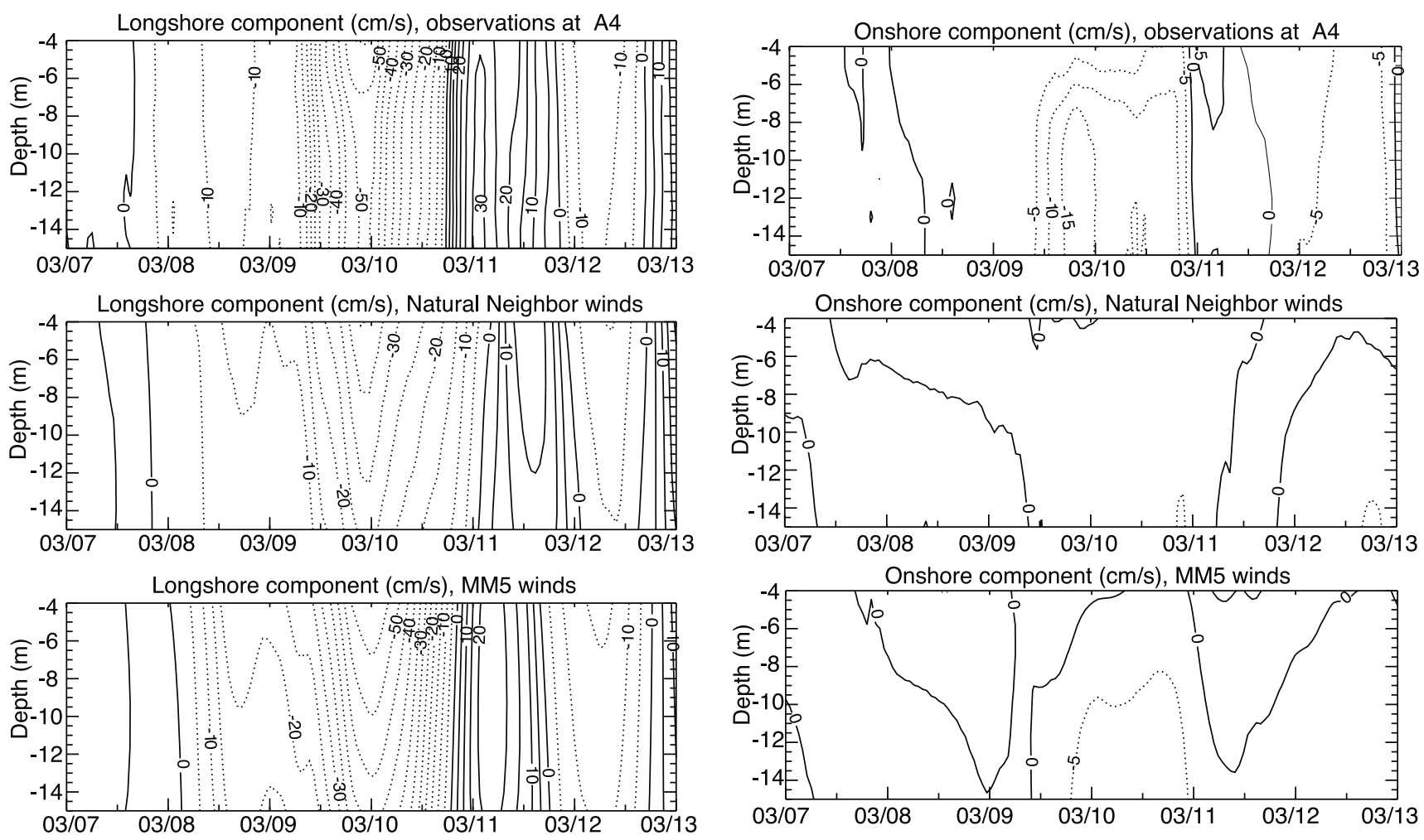

Figure 8. Time series of modeled (Natural Neighbor and MM5) versus observed longshore (a) and onshore (b) currents at station A4.

[20] The model qualitatively reproduces the observed large-scale circulation pattern during peak winds on $9-10$ March. For further analysis and model evaluation both observed and modeled currents were decomposed into longshore and offshore components (a new longshore/ offshore direction was calculated for each mooring location). Major discrepancies occurred at moorings A2, A5, and V12 where the model did not predict the sign of longshore current correctly (Figure 7). At $12 \mathrm{~m}$ depth the model predicted an offshore flow at most stations during 9-10 March (Figure 7). Significant offshore flow was rather accurately predicted at moorings $\mathrm{V} 01, \mathrm{~V} 03$, and V04 while at moorings V06, V12, A1, A2, A4, and A5 the model significantly underestimated strong offshore flow. When the wind relaxed, the two-gyre pattern began to rotate cyclonically around the basin in the form of a topographic wave. The signature of a basin-scale topographic wave is clearly seen in a characteristic cyclonic rotation of currents with a period of $\sim 4$ days (well reproduced by the model) at offshore station CM1 (not shown) [Saylor et al., 1980].

[21] At nearshore stations A1, A4, and V09, modeled currents exhibited a delay in longshore current reversal (Figures 6 and 7). This is clearly seen in the A4 station data where ADCP measurements provided valuable information on vertical current distributions (Figure 8a) (which also contains MM5 results which will be described in the next section). Observations showed strong southerly longshore currents (over $50 \mathrm{~cm} / \mathrm{s}$ ) on 10 March followed by current reversal on 11 March (with northerly currents up to $30 \mathrm{~cm} / \mathrm{s}$ ). Modeled longshore currents also peaked on 10 March at this location although currents were not as strong (up to $40 \mathrm{~cm} / \mathrm{s}$ ). Reversed modeled currents were also weaker than observed $(15 \mathrm{~cm} / \mathrm{s})$. Current reversals in the model lagged observations by $\sim 12$ hours. The model also exhibited excessive vertical shear at A4. The offshore flow was calculated qualitatively correctly at A4 (Figure 8b), but its magnitude was significantly less than observed flow which also showed a pronounced peak $(15 \mathrm{~cm} / \mathrm{s})$ around 1800 UTC on 9 March.

[22] At the offshore station A5, observed southerly currents reached only $20 \mathrm{~cm} / \mathrm{s}$ on 10 March (Figure 9a) but reversed currents were three times stronger, up to $60 \mathrm{~cm} / \mathrm{s}$, on 11 March. The model predicted southerly flow only in the upper layer (with maximum speed of $5 \mathrm{~cm} / \mathrm{s}$ ). Reversed current speed was also too weak: about $30 \mathrm{~cm} / \mathrm{s}$. Observations also showed strong (up to $40 \mathrm{~cm} / \mathrm{s}$ ) offshore flow (Figure 9b) on 11 March while modeled currents were only a few $\mathrm{cm} / \mathrm{s}$. Twelve hours later currents were onshore in both observations $(20 \mathrm{~cm} / \mathrm{s})$ and the model but modeled currents were significantly smaller (only $5 \mathrm{~cm} / \mathrm{s}$ ).

[23] A statistical comparison of modeled and observed currents is presented in the form of the Fourier norms (rms of vector difference). The Fourier norm of time-series of observed current vectors $\mathbf{v}_{\mathbf{o}}$ and computed $\mathbf{v}_{\mathbf{c}}$ is defined as

$$
\left\|\mathbf{v}_{\mathbf{o}}, \mathbf{v}_{\mathbf{c}}\right\|=\left(\frac{1}{M} \sum_{t-\Delta t}^{M \Delta t}\left|\mathbf{v}_{\mathbf{o}}-\mathbf{v}_{\mathbf{c}}\right|^{2}\right)^{1 / 2}
$$

We use a normalized Fourier norm:

$$
F_{n}=\left\|\mathbf{v}_{\mathbf{c}}, \mathbf{v}_{\mathbf{o}}\right\| /\left\|\mathbf{v}_{\mathbf{0}}, \mathbf{0}\right\|
$$

[24] The $F_{n}$ can also be thought of as the relative percentage of variance in the observed currents that is 

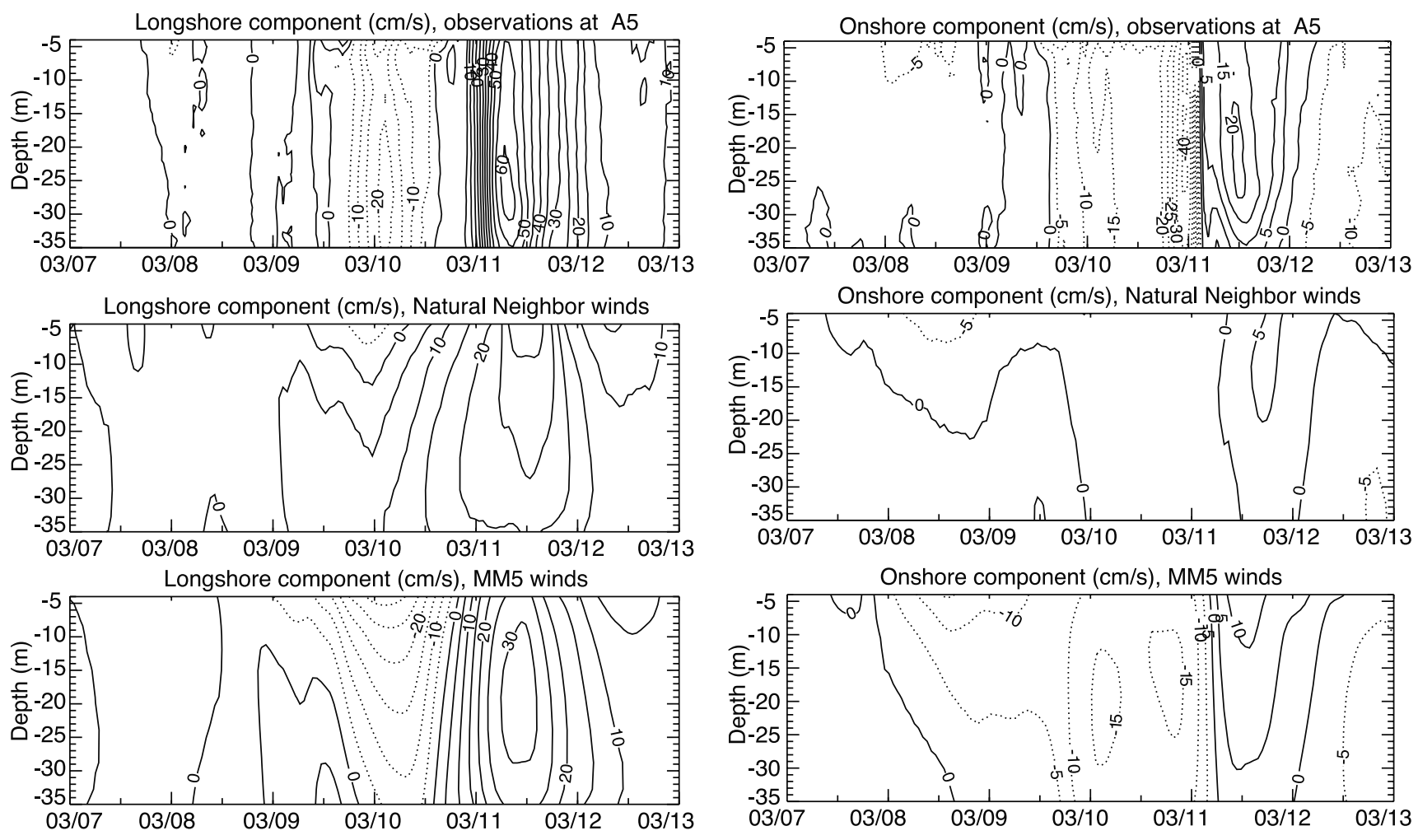

Figure 9. Time series of modeled (Natural Neighbor and MM5) versus observed longshore (a) and onshore (b) currents at station A5.

unexplained by the calculated currents. In the case of perfect prediction $F_{n}=0$. In the case $0<F_{n}<1$, model predictions are better than no prediction at all (zero currents). Using $F_{n}$ allows us to compare our model results more objectively with previous model results. For example, in one of the earlier modeling exercises, Schwab [1983] calculated $0.79<F_{n}<1.01$ for a barotropic simulation of Lake Michigan currents on the $5 \mathrm{~km}$ grid. Later, Beletsky and Schwab [2001] obtained $0.5<F_{n}<0.9$ for coastal current prediction in Lake Michigan in winter, also on a $5 \mathrm{~km}$ grid.

[25] The numbers in Table 1 obtained for a 6-day period around the strongest storm on 9-10 March show significant improvement over previous modeling results which we attribute to higher horizontal resolution in the hydrodynamic model. At the same time the range of $F_{n}$ is quite large indicating that currents at some locations were modeled much more accurately than at others. Overall, currents at 20 meter and 60 meter stations were modeled more accurately $\left(F_{n}=0.57\right.$ and 0.50 , respectively) than at 40 meter moorings $\left(F_{n}=0.71\right)$. Correlation coefficient for modeled and observed currents is rather high: 0.74 for the onshore component and 0.84 for the longshore component.

\section{MM5 Based Model Run}

[26] In the hydrodynamic model run, natural neighbor winds were replaced with MM5 winds during the 7-13 March period. The winds were bilinearly interpolated from the $6 \mathrm{~km}$ MM5 grid to $2 \mathrm{~km}$ model grid and used to calculate momentum and heat fluxes. All other meteoro- logical fields remained unchanged. In particular, the heat flux from the MM5 was not used in hydrodynamic model runs in order to examine the effect of wind field alone. The MM5 winds were calibrated with 45002 observations (Figure 5) by adjusting the nondimensional parameter in the surface roughness formulation given by Charnock [1955]. The hydrodynamic model runs with MM5 winds showed significant improvement in model results (Table 1). The correlation coefficient increased to 0.85 for the onshore flow component and to 0.92 for the longshore component. The ensemble-averaged $F_{n}$ decreased for all groups of stations: to 0.39 and 0.41 at 20 and 60 meter stations, respectively. At 40 meter moorings $F_{n}$ decreased to 0.52 . This improvement was even reflected in monthly average $F_{n}$ which decreased from 0.60 to 0.51 . This indicates the importance of accurate modeling of episodic events since MM5 winds were used only for a 6 day period in a 30-day simulation.

[27] The changes due to new winds are easily seen in model-data comparisons. Thus Figure 10 shows better timing of the nearshore current reversal on 10 March and stronger longshore and onshore currents during wind

Table 1. Statistical Comparison of 7-12 March Observed and Computed Currents (Fourier Norm and Correlation Coefficient)

\begin{tabular}{cccc}
\hline Wind & $F_{n}$ : Range, Mean & $\begin{array}{c}\text { CC Longshore: } \\
\text { Range, Mean }\end{array}$ & $\begin{array}{c}\text { CC Longshore: } \\
\text { Range, Mean }\end{array}$ \\
\hline Natural Neighbor & $0.29-0.80,0.57$ & $0.21-0.90,0.74$ & $0.61-0.98,0.84$ \\
MM5 & $0.30-0.68,0.42$ & $0.65-0.97,0.85$ & $0.78-0.98,0.92$ \\
\hline
\end{tabular}



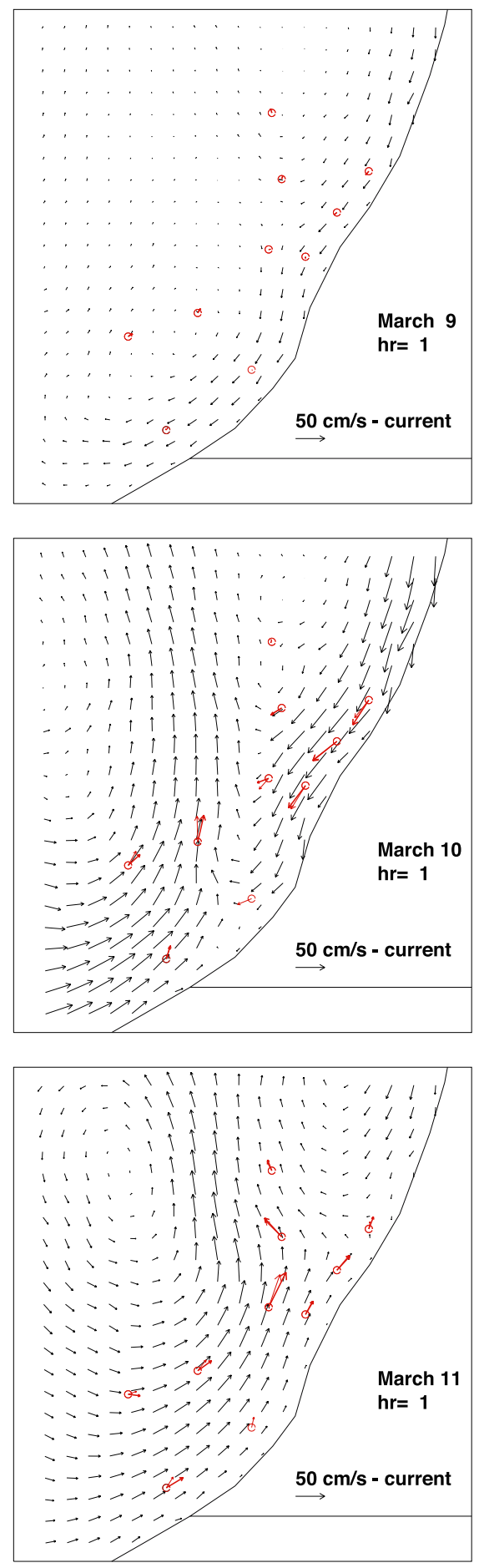
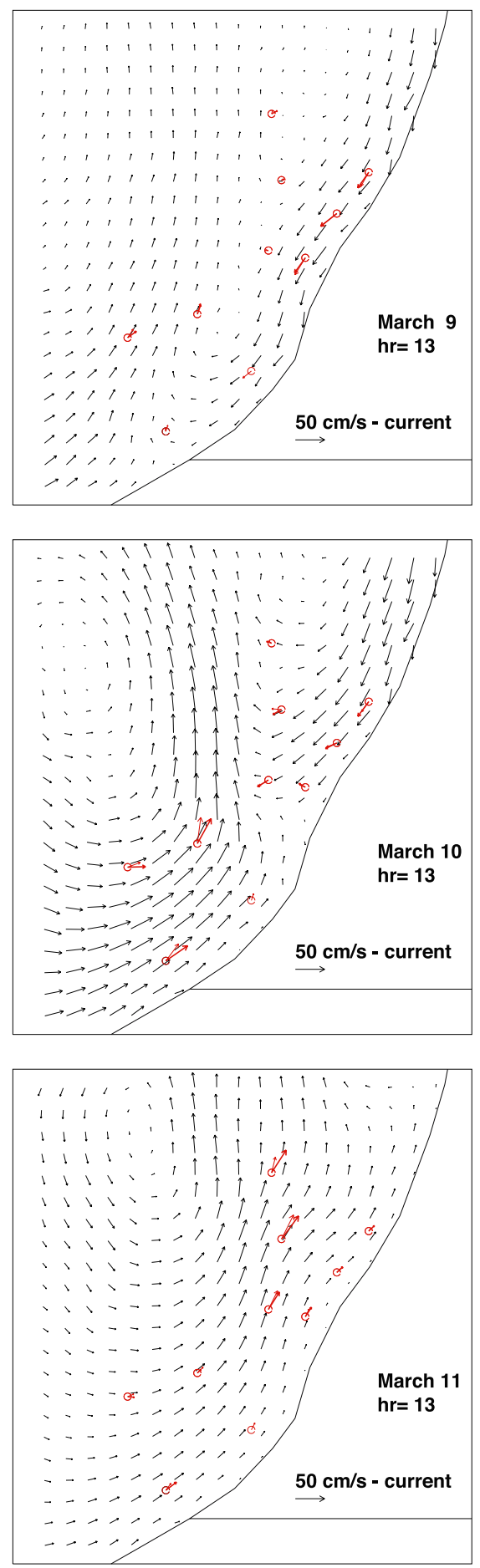

Figure 10. Modeled depth-averaged currents versus observed currents $(12 \mathrm{~m}$ currents are shown in bold) on 9-11 March in southern Lake Michigan. Model is driven with MM5 wind.

events. This is also seen in Figure 8a (bottom panel). Offshore flow was predicted significantly better at all stations (Figure 11) matching observations very closely at V01, V03, and V04. Additional improvements in simulated currents were obtained at V06, A2, A4, A5, and V12, but they were still weaker than observed. The MM5 winds provide better results at ADCP stations A4 and A5 on 12 March (Figure 8b and 9b). At A4, maximum longshore currents increased from 30 to $55 \mathrm{~cm} / \mathrm{s}$ and offshore currents became stronger (more than $5 \mathrm{~cm} / \mathrm{s}$ ). The improvement is especially significant at station A5 where longshore current became several times stronger and has the correct direction from top to bottom on March 12 (Figure 9a). The onshore current shows significant improvement over the case with Natural Neighbor winds (Figure 9b).

\section{Discussion}

[28] In both natural neighbor and MM5 model runs the agreement with observations is better for longshore than 
40 and 60 meter stations
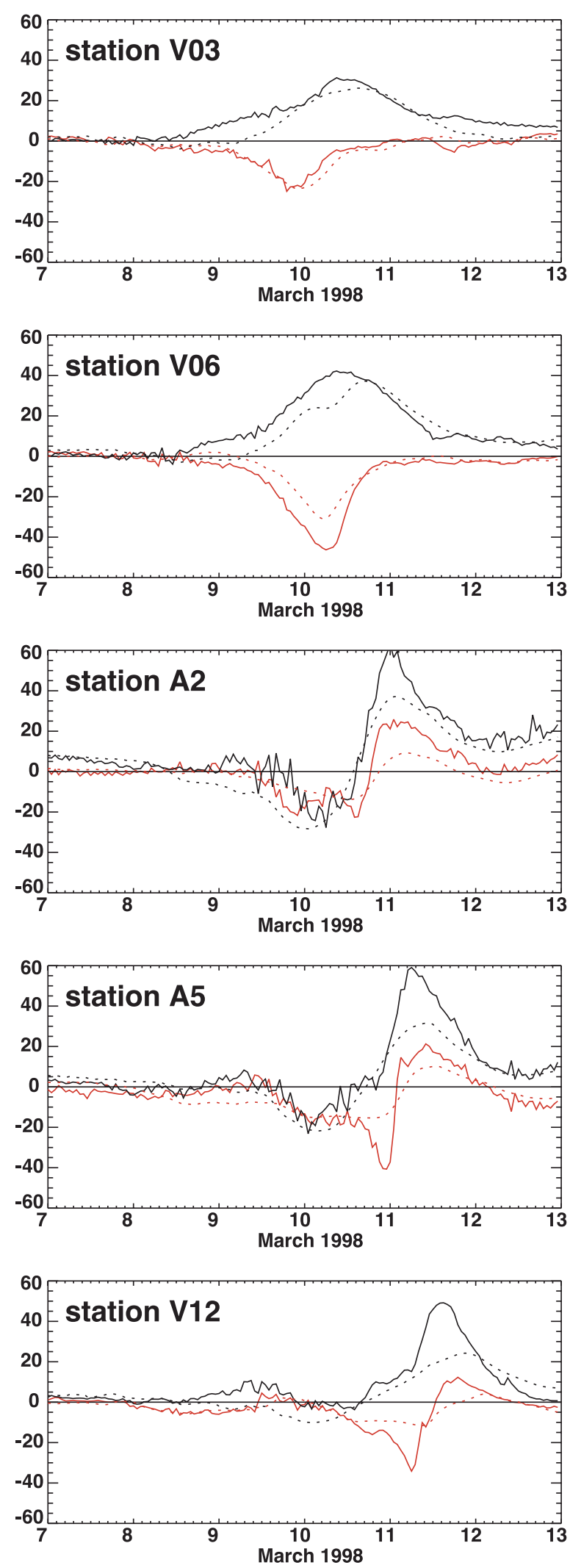

20 meter stations
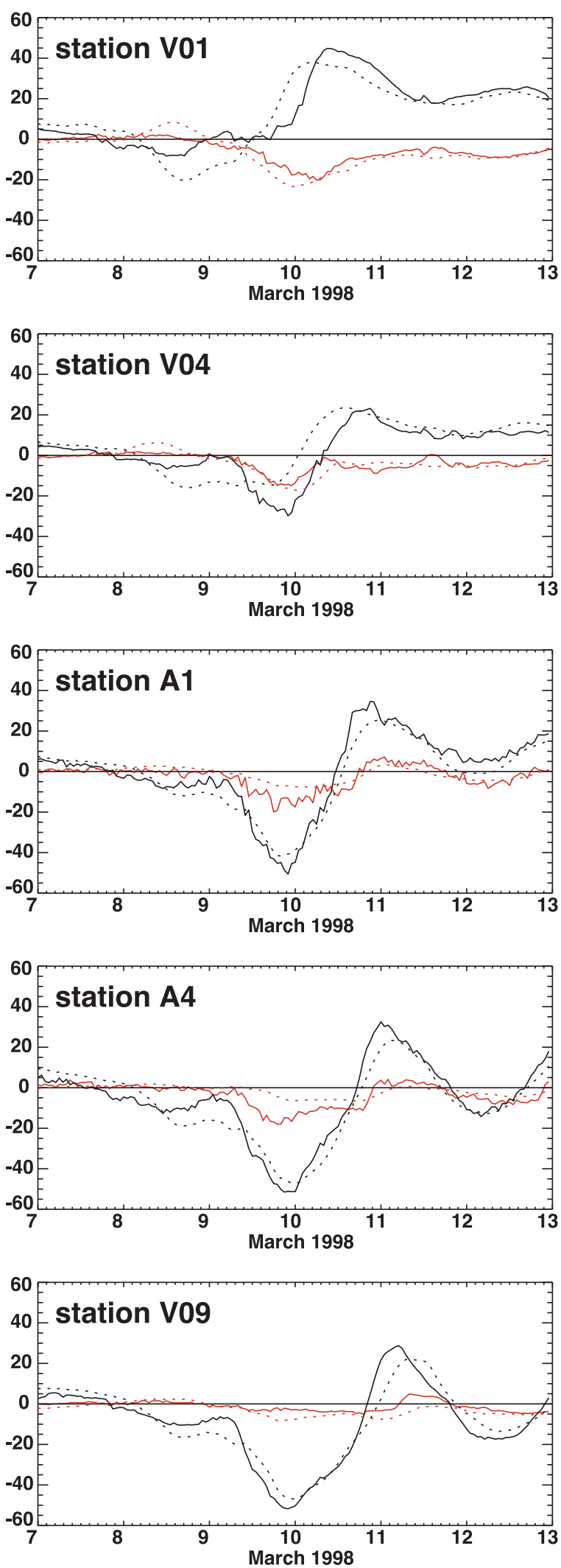

Figure 11. Longshore and offshore currents at $12 \mathrm{~m}$. Solid line is observations; dotted line is MM5 model results. Black represents longshore currents, and red represents onshore (positive) currents. 

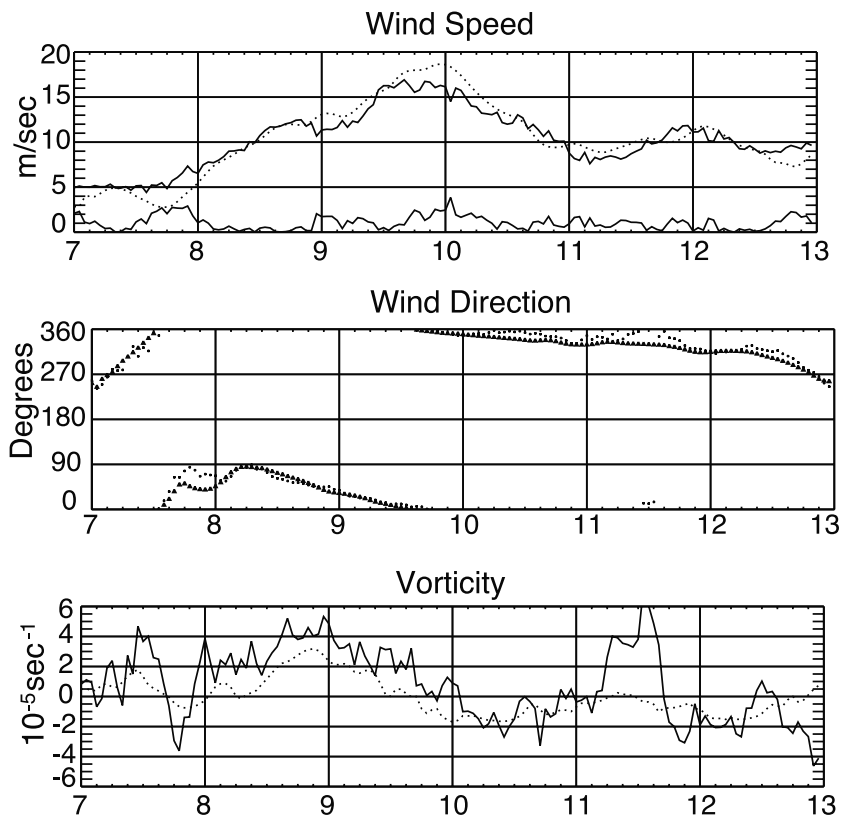

Figure 12. Modeled (dashed line) versus Natural Neighbor (solid line) winds in Lake Michigan. 7-13 March 1998. Thin solid line is their absolute difference.

offshore currents. In general, point-to-point comparison of modeled and observed currents in large lakes is a challenging task because of spatial variability of the current field [Beletsky and Schwab, 2001]. This is especially true for the onshore/offshore current component which is typically an order smaller than longshore component because of a general tendency of lake currents to follow isobaths [Beletsky et al., 1999]. In particular, in a wind-generated two-gyre circulation pattern the most of onshore (offshore) transport occurs in a rather narrow divergence (convergence) zone separating cyclonic and anticyclonic gyres (Figure 6). The coastal circulation pattern can also be influenced by the current instability due to interactions with bottom topography thus making current predictions sensitive to initial conditions.

[29] Besides the conspicuous offshore sediment transport area near mooring A2-A5 in Figure 1, another peculiar example of cross-margin transport in that figure is a spiral eddy-like feature with a center at $42.6^{\circ} \mathrm{N}$ and $86.7^{\circ} \mathrm{W}$. Unfortunately, lack of current measurements prevents us from giving a clear explanation of the origin and dynamics of this feature. Since neither model run produced a localized eddy in that area, one possible explanation can be that a suspended sediment pattern like that could have been produced by a sediment patch moving offshore across the horizontal current shear present in the coastal zone.

[30] Since MM5 winds provided significantly better results than objectively analyzed winds, it is instructive to analyze the differences between the two. Figure 12 shows spatially averaged winds from both the Natural Neighbor technique and MM5. Modeled wind direction follows the Natural Neighbor direction very closely while modeled wind speed was higher than Natural Neighbor's speed on 9-10 March (up to $4 \mathrm{~m} / \mathrm{s}$ higher). Wind vorticity in MM5 is smaller and smoother than in Natural Neighbor which may reflect local effects of land-based stations while the overlake wind field is more uniform.

[31] This is further illustrated in Figure 13 which shows that the spatial differences between Natural Neighbor and MM5 winds can be very significant. Because MM5 winds are crudely calibrated by 45002 observations (through an adjustment of the Charnock formulation for all overwater points that resulted in a closer match between observed and modeled winds at that location), winds differ the most in southern Lake Michigan while discrepancies between the two models are at a minimum in northern Lake Michigan. In addition, the MM5 exhibited a pronounced internal boundary layer due to changes in surface roughness from land to water and vice versa which is lacking in the Natural Neighbor results. This leads (according to 6-day statistics) to persistent differences in winds in the coastal zone (10$20 \mathrm{~km}$ from shore). Another significant difference is that Natural Neighbor interpolation produces too much spatial variability in offshore wind speed during peak winds while MM5 winds are almost uniform outside the internal boundary layer which makes more sense physically.

[32] Figure 14 illustrates the hydrodynamic model error behavior in time. The maximum error in predicted currents occurred on 9 March in MM5 run and 10 and 11 March in both Natural Neighbor and MM5 model runs. The ensemble-averaged error peak on 10 March is due to error peaks in all individual stations while on 11 March it is mostly due to error peaks at A1, A2, A4, and A5 in the NTRL run and due to error peaks at A2 and A5 in the MM5 run.

[33] Overall, Natural Neighbor results were more accurate during 8-9 March while MM5 results were more accurate on 10-11 March. During both periods overall MM5 wind speeds were equal to or higher than Natural Neighbor wind speeds (Figure 12) with the biggest differences during the second period. Therefore it is likely that the difference in hydrodynamic model accuracy was caused by differences in spatial variability of the wind field (seen in Figure 12 as a difference in wind vorticity, for example). We already mentioned the lack of an internal boundary layer and too much spatial variability in Natural Neighbor peak winds which would also affect hydrodynamic model results through the wind stress vorticity mechanism. The importance of wind stress vorticity impact on lake circulation pattern was recently stressed by Schwab and Beletsky [2003].

\section{Summary and Conclusions}

[34] The Princeton ocean model was applied to Lake Michigan to simulate hydrodynamic conditions during the March 1998 sediment resuspension event. The model is driven with objectively analyzed (Natural Neighbor) winds and also with surface winds from the meteorological model MM5. Overall, comparison with observations showed that the hydrodynamic model driven by Natural Neighbor winds was able to qualitatively simulate wind-driven currents in March 1998 but underestimated current speeds during the most significant wind event. In addition, a pronounced offshore flow in the area of observations was also underestimated. Model results with MM5 winds were significantly better than the results that used Natural Neighbor winds. Since four dimensional data assimilation was used to nudge MM5 with the gridded analyses of wind, temperature 

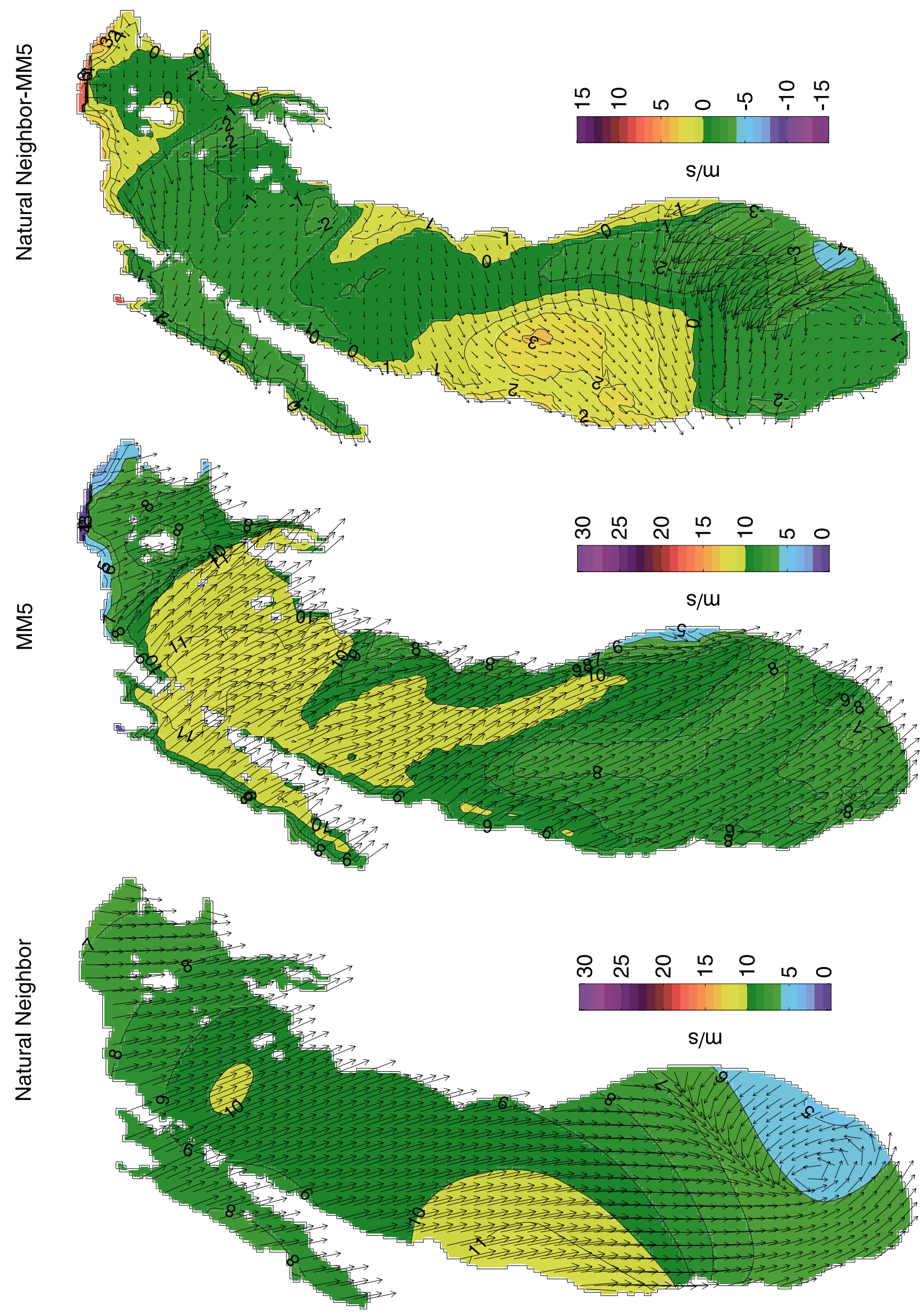

Figure 13. MM5, Natural Neighbor, and their difference winds at 0800 UTC, 11 March 1998. 


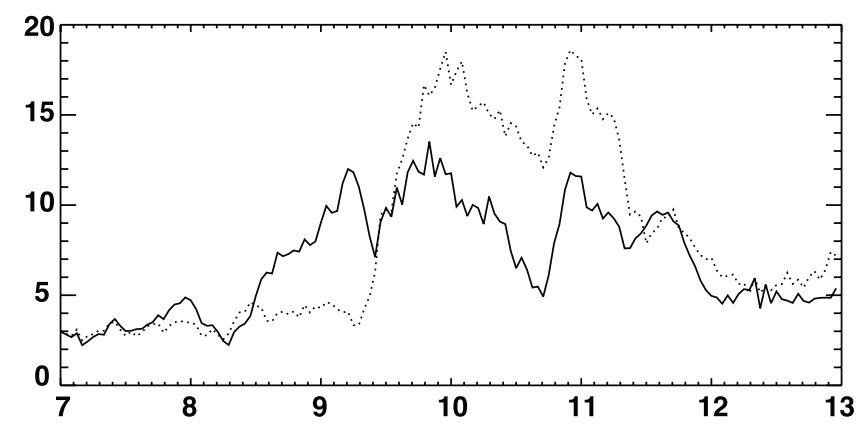

Figure 14. Ensemble-averaged model-observations current vector error magnitude $(\mathrm{cm} / \mathrm{s})$ during 7-12 March. Solid line is MM5 results; dotted line is Natural Neighbor results.

and moisture only on the outermost (54 km grid spacing) domain, these improvements in the hydrodynamic model using winds from the innermost (6 km grid spacing) MM5 domain suggest the importance of the in situ dynamical forcing provided by Lake Michigan. In effect, the physics of the model as applied to the Lake Michigan basin provide a means of dynamically "interpolating" from the large scale to the mesoscale.

[35] Although the MM5 winds yielded better currents than ones calculated with objectively analyzed winds, there is still room for improvement. One such area is improved modeling of surface roughness in MM5, which could be accomplished through coupling of MM5 with hydrodynamic and wave models. Another potential area for improvement is horizontal resolution of wind data in the atmospheric model. In particular, the width of the internal boundary layer in the $6 \mathrm{~km}$ resolution MM5 was probably exaggerated. Finer resolution wind fields should be tested to check the sensitivity of hydrodynamic model results to the accuracy of wind stress vorticity in the nearshore zone.

[36] Acknowledgments. The authors thank two anonymous reviewers for their comments which improved the manuscript. This research is supported by the NSF-OCE 9726679, the National Oceanic and Atmospheric Administration Coastal Ocean Program, and Cooperative Institute for Limnology and Ecosystem Research/NOAA GLERL and University of Michigan. This is NOAA/GLERL contribution 1253.

\section{References}

Beletsky, D., and D. J. Schwab, Modeling circulation and thermal structure in Lake Michigan: Annual cycle and interannual variability, J. Geophys. Res., 106, 19,745-19,771, 2001.

Beletsky, D., J. H. Saylor, and D. J. Schwab, Mean circulation in the Great Lakes, J. Great Lakes Res., 25, 78-93, 1999.
Bennett, J. R., On the dynamics of wind-driven lake currents, J. Phys. Oceanogr., 4, 400-414, 1974.

Blackadar, A. K., High-resolution models of the planetary boundary layer, in Advances in Environmental Science and Engineering, vol.1, edited by J. R. Pfafflin and E. N. Zeigler, pp. 50-85, Gordon and Breach, New York, 1979.

Blumberg, A. F., and G. L. Mellor, A description of a three-dimensional coastal ocean circulation model, in Three-Dimensional Coastal Ocean Models, Coastal Estuarine Sci., vol. 5, edited by N. S. Heaps, pp. $1-$ 16, AGU, Washington, D. C., 1987.

Charnock, H., Wind stress on a water surface, Q. J. R. Meteorol. Soc., 81, 639, 1955.

Cressman, G. P., An operational objective analysis system, Mon. Weather Rev., 87, 367-374, 1959.

Dudhia, J., A nonhydrostatic version of the Penn State-NCAR mesoscale model: Validation tests and simulation of an Atlantic cyclone and cold front, J. Atmos. Sci., 46, 3077-3107, 1993.

Eadie, B. J., et al., Anatomy of a recurrent episodic event: A winter-spring plume in southern Lake Michigan, Eos Trans. $A G U, 77,337-338$, 1996.

Foster, D. S., and S. M. Colman, Thickness and distribution of post glacial deposits beneath Lake Michgan, U. S. Geol. Surv. Misc. Field Stud. Map, MI-2202, 1992.

Mellor, G. L., and T. Yamada, Development of a turbulence closure model for geophysical fluid problems, Rev. Geophys., 20, 851-875, 1982.

Mortimer, C. B., Discoveries and testable hypotheses arising from Coastal Zone Color Scanner imagery of southern Lake Michigan, Limnol. Oceanogr., 33, 203-226, 1988.

National Geophysical Data Center, Bathymetry of Lake Michigan, Rep. $M G G-11,1996$.

Resio, D. T., and C. L. Vincent, Estimation of winds over the Great Lakes, J. Waterw. Port Coastal Ocean Div. Am Soc. Civ. Eng., 102, 265-283, 1977.

Sambridge, M., J. Braun, and H. McQueen, Geophysical parameterization and interpolation of irregular data using natural neighbors, Geophys. J. Int., 122, 837-857, 1995.

Saylor, J. H., J. C. K. Huang, and R. O. Reid, Vortex modes in Lake Michigan, J. Phys. Oceanogr., 10, 1814-1823, 1980.

Schwab, D. J., Numerical simulation of low-frequency current fluctuations in Lake Michigan, J. Phys. Oceanogr., 13, 2213-2224, 1983.

Schwab, D. J., and D. Beletsky, The relative effect of wind stress curl, topography, and stratification on large-scale circulation in Lake Michigan, J. Geophys. Res., 108, doi:10.1029/2001JC001066, in press, 2003.

Sibson, R., A brief description of Natural Neighbor Interpolation, in Interpreting Multivariate Data, edited by V. Barnett, pp. 21-36, John Wiley, New York, 1981.

Stauffer, D. R., and N. L. Seaman, Use of four-dimensional data assimilation in a limited-area mesoscale model, I, Experiments with synopticscale data, Mon. Weather Rev., 118, 1250-1277, 1990.

Watson, D., An Implementation of Natural Neighbor Interpolation, Dave Watson, Claremont, Australia, 1994.

D. Beletsky, Department of Naval Architecture and Marine Engineering, University of Michigan, 1600 Draper Road, Ann Arbor, MI 48109, USA. (dima.beletsky@noaa.gov)

M. J. McCormick, G. S. Miller, J. H. Saylor, and D. J. Schwab, NOAA Great Lakes Environmental Research Laboratory, 2205 Commonwealth Blvd., Ann Arbor, MI 48105, USA. (michael.mccormick@noaa.gov; david. schwab@noaa.gov)

P. J. Roebber, Department of Mathematical Sciences, University of Wisconsin-Milwaukee, Lapham Hall 352, P. O. Box 413, Milwaukee, WI 53201, USA. (roebber@csd.uwm.edu) 